\title{
Does anthracene affect microbial activities and organic matter decomposition? A comparative study in Pinus halepensis litters from Mediterranean coastal and inland areas
}

\author{
Leila Qasemian ${ }^{\mathrm{a}, *}$, Daniel Guiral ${ }^{\mathrm{a}}$, Fabio Ziarelli ${ }^{\mathrm{b}}$, Florence Ruaudel ${ }^{\mathrm{a}}$, Anne-Marie Farnet ${ }^{\mathrm{a}}$ \\ ${ }^{a}$ Equipe Systèmes Microbiens IMBE, UMR CNRS 7263, IRD 237, Faculté des Sciences et Techniques de St. Jérôme, 13397, Cedex 20, Marseille, France \\ ${ }^{\mathrm{b}}$ TRACES Université Paul Cézanne, Faculté des Sciences et Techniques de St. Jérôme, 13397, Cedex 20, Marseille, France
}

\section{H I G H L I G H T S}

- Microbial functions in litters are assessed in the presence of anthracene.

- Coastal and inland microbial communities from Pinus halepensis are compared.

- Anthracene showed no toxic effects on microbial activities in both litters.

- Microbial activities differ greatly according to litter origin.

\begin{abstract}
A B S T R A C T
The widespread concern about pollution caused by Polycyclic Aromatic Hydrocarbons (PAHs) raises the question of how they affect soil microbial communities which are potentially involved in the transformation of these pollutants. Using microcosms, we describe the effect of anthracene, a model PAH, on microbial communities inhabiting a Pinus halepensis litter from both coastal (COS) and inland (INL) Mediterranean sites. The microcosms were incubated over 3 months $\left(25^{\circ} \mathrm{C}, 60 \% \mathrm{WHC}\right)$ and the effects of anthracene on microbial activities of both litters were monitored. Different enzyme activities (laccase, cellulase, $\beta$-glucosidase and acid phosphatase) and microbial respiration were measured and variations in litter chemical composition over incubation were determined using ${ }^{13} \mathrm{C}$ Nuclear Magnetic Resonance (NMR) from both sites. Our results show that lignocellulolytic enzymes increased markedly after a 3-month incubation in COS microcosms, especially in the presence of anthracene, whereas INL microcosms were not similarly affected. These results show that anthracene not only has no toxic effect on the microbial activities tested but actually enhances the lignocellulolytic activities of the fungal communities from coastal litters, demonstrating the detoxification potential and resistance of stressed Mediterranean coastal ecosystems.
\end{abstract}

\section{Introduction}

Large quantities of pyrogenic Polycyclic Aromatic Hydrocarbons (PAHs) are continuously released into the atmosphere as by-products of incomplete combustion via leaking automobile fuel, incineration of waste and industrial exhaust systems (Johnsen and Karlson, 2007; Sorgi, 2007; Fernández-Luqueño et al., 2011). Complex recalcitrant organic molecules, PAHs are recognized as an environmental contamination problem of worldwide magnitude (Andreoni and Gianfreda, 2007; Marusenko et al., 2011). During the past few years, particular attention has been paid to chronic pollution through $\mathrm{PAH}$ deposits on vegetation and in soils especially in peri-urban areas

\footnotetext{
* Corresponding author. Tel.: +33 4912885 28; fax: +33 491288190 .

E-mail address: leila_qasemian@yahoo.com (L. Qasemian).
}

(Johnsen et al., 2005; Johnsen and Karlson, 2007). Studies have examined accumulations of PAHs on leaves and needles of plants, showing that vegetation plays an important role in the transfer of PAHs from air to soil especially by direct deposition from plants to topsoil (Holoubek et al., 2000; Howsam et al., 2001; Berg and Laskowski, 2006; Yutthammo et al., 2010).

Mediterranean ecosystems are characterized by specific pedoclimatic conditions (summer drought, calcareous soils, etc.) and are additionally subjected to intense anthropic activities caused by increasing urbanization. Several studies also point to the presence of PAHs as chronic anthropic pollutants on French Mediterranean coastal areas (Mille et al., 2007; Asia et al., 2009) which are also subjected to salinity. While the ways in which microorganisms mineralize organic contaminants have been extensively documented in studies on bioremediation technologies (Gianfreda and 
Rao, 2004; Novotný et al., 2004; D’Annibale et al., 2006; Wu et al., 2008), little is known about how far autochthonous microbial communities can withstand PAHs and whether they may be involved in degrading theses pollutants. In our previous study, we showed that anthracene, a model PAH, artificially added in laboratory experiments (Qasemian et al., 2011, 2012) has no toxic effects on microbial activities expressed by whole microbial communities in Pinus halepensis litter from a coastal Mediterranean site. It therefore appeared useful to compare these results obtained from litters in coastal environments with the responses of microbial communities from inland areas.

Microbial community composition is known to depend greatly on the chemical composition of organic matter, thus differing according to plant chemical composition (Berg and McClaugherty, 2008; Nazareno Saparrata et al., 2008; Sariyildiz et al., 2005). Indeed, microorganisms associated with the same plant species in the same climatic context are supposed to be functionally equivalent and on the whole to harbor the same degrader communities (Costa et al., 2006; Ayres et al., 2009; Strickland et al., 2009). Considering that microbial degradation depends on the chemical composition of litter and on the degradation ability of indigenous microorganisms influenced by environmental factors, we hypothesized that, depending on the origin of the litters, anthracene might have differing effects on microbial communities from different $P$. halepensis litters under the same laboratory conditions.

Here, we compare the effect of anthracene on microbial communities from $P$. halepensis litter originating from both coastal and inland Mediterranean sites. P. halepensis litters were collected and anthracene, as a model PAH, was artificially added to the litter in the laboratory. The effect of this pollutant on whole microbial communities was monitored through extracellular enzyme measurement and microbial respiration combined with ${ }^{13} \mathrm{C}$ Nuclear Magnetic Resonance (NMR), in order to precisely determine the chemical variations in the litters from both sites.

\section{Materials and methods}

\subsection{Litter sampling}

A composite sampling was performed in November 2010 from partially degraded litter of Aleppo pine ( $P$. halepensis L.) from two sites under Mediterranean climate, one from a coastal area (massif de Marseilleveyre, $43^{\circ} 12^{\prime} 34^{\prime \prime} \mathrm{N}, 5^{\circ} 21^{\prime} 36^{\prime \prime} \mathrm{E}$ ) and one from inland (massif de la Trevaresse, $43^{\circ} 36^{\prime} 88^{\prime \prime} \mathrm{N}, 5^{\circ} 27^{\prime} 72^{\prime \prime} \mathrm{E}$ ), hereafter respectively referred to as COS and INL. The litters were sieved at $2 \mathrm{~mm}$ mesh size, homogenized and stored overnight at $4{ }^{\circ} \mathrm{C}$ before being used in microcosms.

Total Organic Carbon (TOC) and total Nitrogen were measured as follows: oven-dried sub-samples of initial litter and of each microcosm litter were powdered in a ceramic mortar and analyzed by combustion in an Elemental Analyzer, FlashEA 1112, Thermofisher.

\subsection{Microcosm preparation}

The litter from each site was placed in $2.6 \mathrm{~L}$ glass jars $(25 \times 20 \times 7 \mathrm{~cm})$ containing $50 \mathrm{~g}$ of litter (dry weight, DW) per microcosm, covered with pierced lids to favor oxygen diffusion. Anthracene microcosms (ANT) were prepared as follows: $40 \mathrm{mg}$ of anthracene was dissolved in dichloromethane and added to a sub-sample of litter ( $10 \mathrm{~g}$ DW of litter) in order to minimize the harmful side-effects of solvent. After dichloromethane evaporation, the sub-sample was mixed with the litter of the microcosm (40 g DW). Two different control microcosms were also performed: a control microcosm (C) i.e. litter without any treatment, and a solvent control microcosm $(\mathrm{S}-\mathrm{C})$ containing a sub-sample of litter treated with solvent alone. Each microcosm type (C, S-C, ANT) was realized in four replicates $(n=4)$ and incubated at $25^{\circ} \mathrm{C}$ in the dark for 3 months. Thus, a total of 12 microcosms were prepared for each site. Humidity of the samples was maintained constant over incubation at $60 \%$ of the $\mathrm{WHC}_{\max }$ by adding sterilized water to the microcosms.

\subsection{Extracellular enzyme activities (EEA)}

Laccase, cellulase, $\beta$-1,4-glucosidase and acid phosphomonoesterases were quantified both in initial litters and after the 3-month incubation. All the enzyme activities were measured using an enzyme extract from litter according to a modified protocol from Criquet et al. (1999). Briefly, $10 \mathrm{~g}$ of litter was added to $200 \mathrm{~mL}$ $\mathrm{CaCl} 2,2 \mathrm{H}_{2} \mathrm{O}(200 \mathrm{mM})$ and $0.1 \%$ Tween 80 , and then shaken for $1 \mathrm{~h}(500 \mathrm{rpm})$. The floating debris was removed, the extract was centrifuged $(7,000 \mathrm{~g}$ for $20 \mathrm{~min})$ and the supernatant was filtered (Whatman $\mathrm{GF} / \mathrm{C}$ ). The filtrate was concentrated by dialysis tubes (12-14 KDa-porosity) using Poly-Ethylene Glycol (PEG). Concentrated extract was obtained by adding $15 \mathrm{~mL}$ of $10 \mathrm{mM}$ BisTris buffer $(\mathrm{pH} 6)$. The reaction mixtures for all the enzyme activities performed with the enzyme extract consisted of $300 \mu$ l of enzyme extract with $700 \mu \mathrm{l}$ of the corresponding buffer at $30^{\circ} \mathrm{C}$, except for cellulase activity, which was incubated at $50^{\circ} \mathrm{C}$. Laccase activity was measured by monitoring the oxidation of syringaldazine to its quinone $\left(\varepsilon^{\mathrm{M}}=65,000 \mathrm{M}^{-1} \mathrm{~cm}^{-1}\right)$ at $525 \mathrm{~nm}$ in acetate buffer (100 mM, pH 4.5). CM-cellulase (EC 3.2.1.4) activity was assayed using Carboxy Methyl Cellulose (CMC) at $0.7 \%(\mathrm{w} / \mathrm{v})$ as substrate with sodium acetate buffer ( $50 \mathrm{mM}, \mathrm{pH} 6)$. After a 4 h-incubation, the glucose released was quantified according to Farnet et al. (2010). $\beta$-1,4-glucosidase activity was performed using $p$-nitrophenyl $\beta$-D-glucopyranoside $(0.2 \mathrm{mM})$ with sodium acetate buffer (100 mM, pH 5.6). Acid phosphomonoesterases were assayed using p-nitrophenyl phosphate monoester $(0.2 \mathrm{mM})$ in sodium acetate buffer (100 mM, pH 4.5). p-nitrophenol was quantified at $412 \mathrm{~nm}$ after the addition of $\mathrm{NaOH}(0.5 \mathrm{M})$. All analytical experiments were performed in triplicate for each microcosm. One unit (U) of enzyme activity is defined as one $\mu$ mole of the reaction product formed per $\mathrm{h}$ and per $\mathrm{g}$ of litter dry weight $\left(\mathrm{U} \mathrm{gdw}^{-1}\right)$.

Enzyme extracts were further subjected to gel electrophoresis according to Qasemian et al. (2011) in order to compare the phenoloxidase bands, as revealed by activity, under each treatment.

\subsection{Basal and induced respiration}

$2 \mathrm{~g}$ Of litter of each microcosm was placed in glass jars $(117 \mathrm{~mL})$, flushed with fresh air and closed by rubber septum before incubation at $25^{\circ} \mathrm{C}$ for $4 \mathrm{~h}$. The concentration of $\mathrm{CO}_{2}$ was measured at the end of incubation by injecting one milliliter of the jar headspace gas into a gas chromatograph (Chrompack CHROM 3-CP 9001 ), equipped with a thermal conductivity detector and a fused silica capillary column $(10 \mathrm{~m} \times 0.53 \mathrm{~mm})$. Glucose was added (25 $\mathrm{mg} \mathrm{g}^{-1}$ of litter dry weight) $90 \mathrm{~min}$ prior to a 90 min-incubation at $25^{\circ} \mathrm{C}$ for induced respiration. Microbial respiration was expressed as $\mu \mathrm{g}$ of $\mathrm{C}$ formed as $\mathrm{CO}_{2}$ per gram of dry litter per hour.

\subsection{Solid-state ${ }^{13} \mathrm{C} C P / M A S N M R$}

Both the initial litters and the litters in each incubated microcosm were characterized by solid-state ${ }^{13} \mathrm{C} C \mathrm{CP} / \mathrm{MAS}$ NMR on a spectrophotometer Bruker DSX $400 \mathrm{MHz}$ operating at $100.7 \mathrm{MHz}$. Samples $(400 \mathrm{mg}$ ) were spun at $10 \mathrm{kHz}$ at the magic angle. Contact times of 2 ms were applied with a pulse width of $2.8 \mu$ s and a recycle delay of $3 \mathrm{~s}$. Chemical shift values were referenced to tetramethylsilane and calibrated to glycine carbonyl signal set at $176.03 \mathrm{ppm}$. The relative $\mathrm{C}$ distribution in ${ }^{13} \mathrm{C}$ NMR spectra was 
determined by integrating the signal intensity in different chemical shift defined using Dmfit 2003 (Massiot et al., 2002).

Seven common chemical shift regions were defined according to Mathers et al. (2003): alkyl C (0-45 ppm), methoxyl C (4560 ppm), O-alkyl C(60-92 ppm), di-O-alkyl C (92-112 ppm), aromatic C (112-142 ppm), phenolic C (142-160 ppm) and carboxyl C (160-185 ppm). Guaiacyl units were considered individually at 148 ppm. Two decomposition indexes were calculated according to Baldock et al. (1997): (alkyl C/O-alkyl C) was taken as the humification ratio, and an aromaticity ratio was calculated by dividing the sum of aromatic $C$ and phenolic $C$ by the sum of all regions except carboxyl C.

\subsection{Statistical analysis}

Two-way ANOVA was performed taking into account litter location (COS, INL) and treatment (C, SC and ANT) followed by a Fisher's LSD post-hoc test. Data were transformed as necessary to respect the normality and homogeneity of variance. The significance of microbial respiration mean differences was tested following non-parametric comparison of Kruskal-Wallis. Pearson correlation was tested between enzyme activities and chemical groups defined by ${ }^{13} \mathrm{C}$ NMR and $\mathrm{C} / \mathrm{N}$ ratio $(n=24)$. Principal Component Analysis (PCA) was performed on ${ }^{13} \mathrm{C}$ NMR considering all peaks of NMR spectra as variables (23 variables). A second PCA was performed considering only the variables most correlated to factorial plot $\left(r^{2}>0.5\right)$ having at least one peak in each chemical group (10 variables).

\section{Results}

\subsection{Comparison of enzyme activities and microbial respiration}

Enzyme activities measured in both litters (COS and INL) before incubation show laccase and cellulase activities at similar values in both litters with $\beta$-glucosidase and phosphatase activities higher in
COS litter than in INL litter (Fig. 1). After a 3-month incubation, the results of means comparison using ANOVA on enzyme activities in microcosms are shown in Table 1 . The factor litter origin significantly affects all enzyme activities, especially laccase activities and the factor microcosm treatment, either alone or with litter origin, shows a significant effect, respectively on laccases and cellulases. Fig. 1 shows the mean of each enzyme in the different microcosms C, SC and ANT of both COS and INL litters. For all the enzymes measured in this study we observed a higher level in COS microcosms after incubation than before, and a higher level than in INL microcosms. Furthermore, the highest levels of both laccase and cellulase activities were observed in the ANT microcosms of COS and cellulase activities significantly differed from controls (SC and C, Fig. 1b) only for ANT microcosms. In INL microcosms, treatment had no effect on enzyme activities, i.e. C, SC and ANT had the same level of enzymes after a 3-month incubation. In COS microcosms, phosphatase activities were significantly lower in SC than in C and ANT microcosms.

Compared to their initial level, laccase activities strongly increased in COS microcosms up to 1000 fold. Gel electrophoresis

Table 1

Two-way ANOVA on enzyme activities as dependent variables measured on Pinus halepensis litters in microcosms after a 3-month incubation. Factors are: litter origin (COS, INL), mecososm treatment (ANT, SC and C).

\begin{tabular}{lllll}
\hline Variables & & Litter & Treatment & Litter $\times$ treatment \\
\hline Laccase & $\mathrm{F}$ & 436.24 & 3.89 & 0.77 \\
& $p$ & $\mathbf{< . 0 0 0 1}$ & $\mathbf{< 0 . 0 5}$ & $\mathrm{ns}$ \\
Cellulase & $\mathrm{F}$ & 20.22 & 2.22 & 3.56 \\
& $p$ & $<\mathbf{0 . 0 0 1}$ & $\mathrm{ns}$ & $\mathbf{< 0 . 0 5}$ \\
$\beta$-Glucosidase & $\mathrm{F}$ & 50.88 & 1.08 & 1.83 \\
Acid phosphatase & $p$ & $\mathbf{< 0 . 0 0 0 1}$ & $\mathrm{ns}$ & $\mathrm{ns}$ \\
& $\mathrm{F}$ & 26.95 & 1.80 & 0.84 \\
& $p$ & $\mathbf{< . 0 0 0 1}$ & $\mathrm{ns}$ & $\mathrm{ns}$ \\
\hline
\end{tabular}

Significant effects are marked bold.
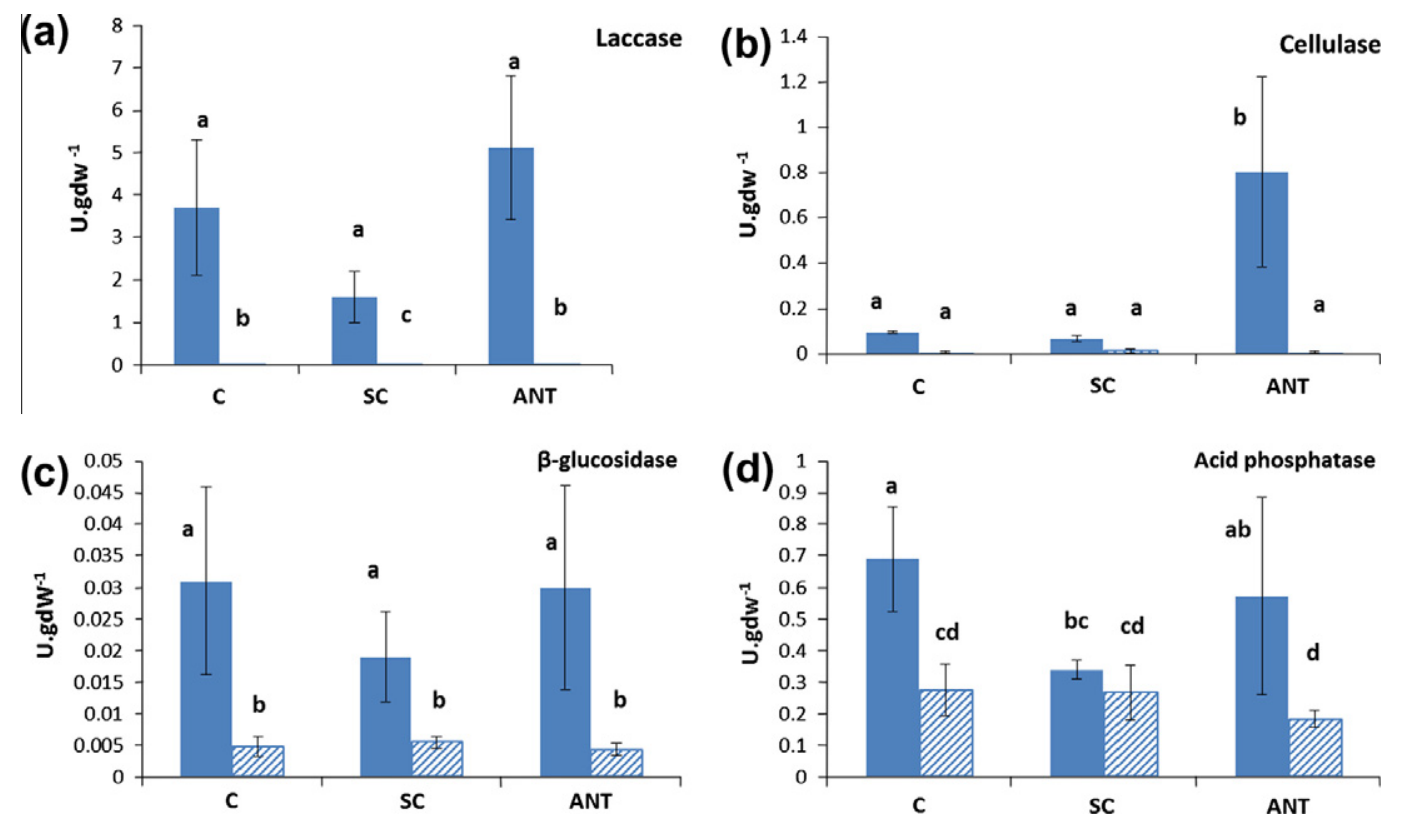

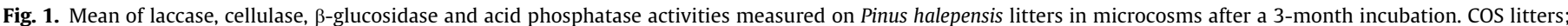

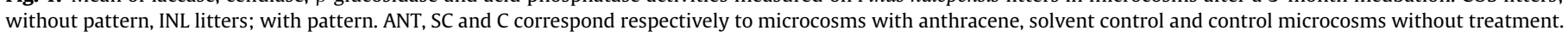

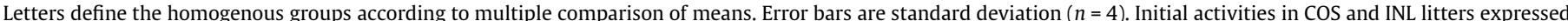

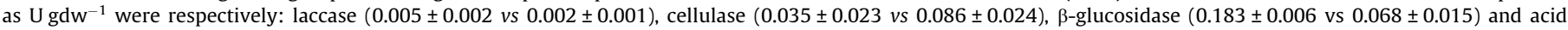
phosphatase $(0.569 \pm 0.022$ vs $0.406 \pm 0.056)$. 

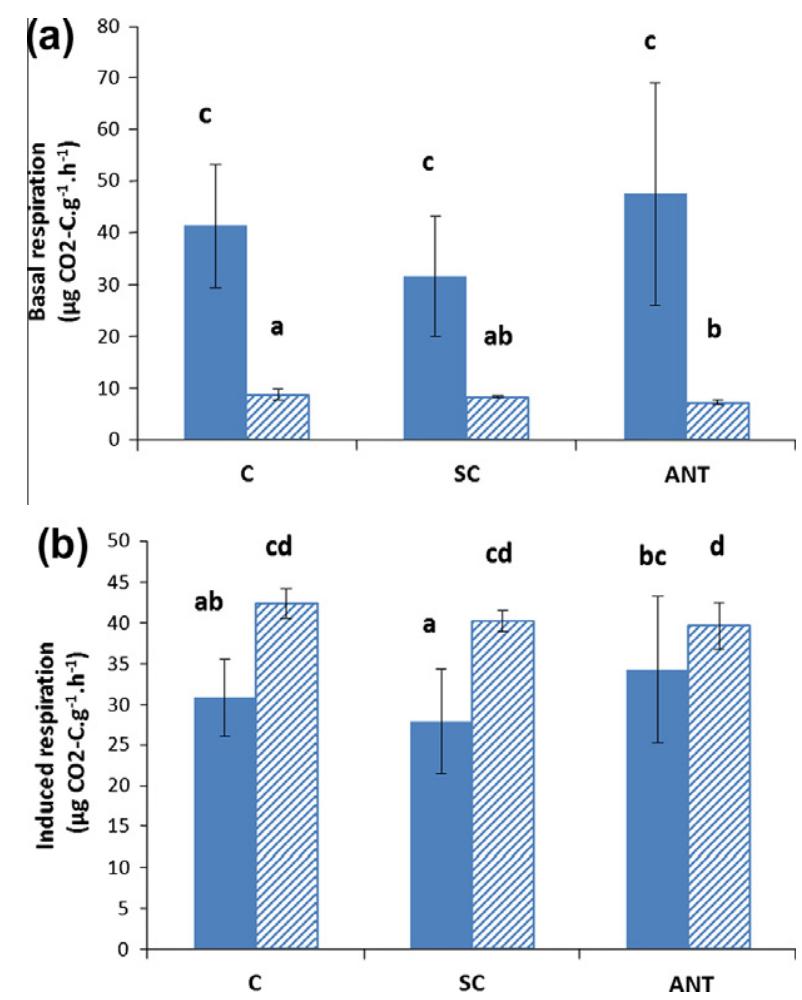

Fig. 2. Basal (a) and Induced (b) respiration measured on Pinus halepensis litters in microcosms after a 3-month incubation. COS litters; without pattern, INL litters; with pattern. ANT, SC and C correspond respectively to microcosms with anthracene, solvent control and control microcosms without treatment. Letters define the homogenous groups according to multiple comparison of means. Error bars are standard deviation $(n=4)$. Initial respiration in COS and INL litters expressed as $\mu \mathrm{g} \mathrm{CO}_{2}-\mathrm{C} \mathrm{g}^{-1} \mathrm{~h}^{-1}$ were respectively: $205 \pm 4$ vs $152 \pm 7$ for basal respiration and $35 \pm 2$ vs $28 \pm 1$ for induced respiration.

of the enzyme extract stained by enzyme activity revealed three low molecular weight bands whatever the microcosms, but these bands were strongly stained in the ANT microcosms (shown as supplementary information). On the other hand, in INL microcosms, laccase activities were too low for bands stained by activity to be observed, even in the ANT microcosms.

Basal and induced respirations were estimated in order to show the impact of anthracene on global activity of microorganisms in microcosms. The values obtained for each litter before incubation were higher in COS litters than those in INL litters: $205 \pm 4$ vs $152 \pm 7$ for basal respiration and $35 \pm 2$ vs $28 \pm 1$ for induced respiration. After a 3-month incubation, while basal respiration values differ greatly between coastal and inland litters, the microcosms treated with anthracene show no effect (Fig. 2a). Nor does the treatment affect induced respiration, although adding glucose induced respiration of microbial communities in INL litter but not in COS litter (Fig. 2b).

\subsection{Comparison of chemical composition}

Litter chemical characteristics were determined in initial COS and INL litters as well as in microcosms after incubation using ${ }^{13} \mathrm{C}$ NMR and $\mathrm{C} / \mathrm{N}$ ratio. $\mathrm{C} / \mathrm{N}$ ratio was not significantly different in $\operatorname{COS}(21.6 \pm 0.4)$ and INL $(22.6 \pm 0.6)$ litters before incubation. However, after incubation, the $\mathrm{C} / \mathrm{N}$ ratios of $\mathrm{COS}$ and INL litters were significantly different, except in SC microcosms (shown as supplementary information), treatment did not show any effect. Comparison of the percentages of different chemical groups defined with ${ }^{13} \mathrm{C}$ NMR spectra showed that the initial litters were chemically different: the percentages of O-alkyl and di-O-alkyl C were higher in INL litter than in COS litter: $39.2 \pm 0.9 v s$ $36.9 \pm 0.4$ and $23.1 \pm 1.2$ vs $27.1 \pm 0.5$, respectively. Table 2 shows the result of mean comparison of chemical groups using ANOVA and considering litter origin and/or treatment as factors. We observed that litter origin (COS or INL) has a significant effect on the variations in certain chemical groups in litters in microcosms after a 3-month incubation: O-alkyl and di-O-alkyl C, which already differed between COS and INL at $\mathrm{t} 0$, and alkyl $\mathrm{C}$ and guaiacyl units. $\mathrm{C} / \mathrm{N}$ and humification ratio also differed between COS and INL. Treatment considered alone or with litter origin has a significant effect respectively on means of guaiacyl units and carboxyl C.

Fig. 3 shows the means of chemical groups in C, SC and ANT microcosms of COS and INL, which were significantly different according to Table 2 . We observed that COS litter had a higher Alkyl C signal and humification ratio than INL litter, whatever the microcosms. However, O-alkyl C, di-O-alkyl C and guaiacyl units were always higher in INL than in COS litter. Treatments (ANT microcosms) lowered the percentage of guaiacyl units and raised the percentage of Carboxyl $\mathrm{C}$ in COS.

To define the correlations between all the chemical groups, a PCA was performed considering all the peaks (23 peaks) of the NMR spectra (Fig. 4a). COS (circles) and INL (triangles) were clearly separated by PC1 $(22.7 \%)$ with a negative and positive correlation, respectively. However, PC2 (16.6\%) mainly separated the microcosms according to their treatment. For INL litter, microcosms treated with anthracene (ANT) were close to the initial litter, while controls ( $C$ and SC) were separated by PC2. On the other hand, for COS litter, C, SC and ANT microcosms were separated according to PC2. To better distinguish the position of each microcosm, a second PCA was subsequently performed, selecting the best correlated variables (peaks) belonging to each chemical group (Fig. 4b). PC1 and PC2 together accounted for $66 \%$ of the variance in this PCA. COS litter was separated from INL litter by a negative correlation with di-O-alkyl and O-alkyl compounds and by a positive

Table 2

Two-way ANOVA on different ${ }^{13} \mathrm{C}$ NMR signals corresponding to different chemical groups detected on Pinus halepensis litters in microcosms after a 3-month incubation. Factors are: litter origin (COS, INL), microcosm treatment (ANT, SC and C).

\begin{tabular}{|c|c|c|c|c|}
\hline Variables & & Litter & Treatment & Litter $\times$ treatment \\
\hline \multirow[t]{2}{*}{ Alkyl C } & $\mathrm{F}$ & 150.9 & 1.5 & 0 \\
\hline & $p$ & $<0.0001$ & ns & ns \\
\hline \multirow[t]{2}{*}{ Methoxyl C } & $\mathrm{F}$ & 0 & 0.93 & 2.48 \\
\hline & $p$ & ns & ns & ns \\
\hline \multirow[t]{2}{*}{ O-Alkyl C* } & $\mathrm{F}$ & 28.9 & 1.3 & 1.9 \\
\hline & $p$ & $<0.0001$ & ns & ns \\
\hline \multirow[t]{2}{*}{ di-O-Alkyl C } & $\mathrm{F}$ & 16.561 & 1.28 & 2.14 \\
\hline & $p$ & $<0.001$ & ns & ns \\
\hline \multirow[t]{2}{*}{ Aromatic C } & $\mathrm{F}$ & 0.51 & 2.55 & 1.03 \\
\hline & $p$ & ns & ns & ns \\
\hline \multirow[t]{2}{*}{ Phenolic C } & $\mathrm{F}$ & 0.58 & 3.30 & 0.89 \\
\hline & $p$ & ns & ns & ns \\
\hline \multirow{2}{*}{$\begin{array}{c}\text { Phenolic C (C3-C4 of } \\
\text { guaiacyl units) }\end{array}$} & $\mathrm{F}$ & 13.27 & 7.41 & 1.41 \\
\hline & $p$ & $<0.01$ & $<0.01$ & ns \\
\hline \multirow[t]{2}{*}{ Carboxyl C } & $\mathrm{F}$ & 0.07 & 1.42 & 3.64 \\
\hline & $p$ & ns & ns & $<0.05$ \\
\hline \multirow[t]{2}{*}{ Aromaticity ratio* } & $\mathrm{F}$ & 0.96 & 1.78 & 0.66 \\
\hline & $p$ & ns & ns & ns \\
\hline \multirow[t]{2}{*}{ Humification ratio } & $\mathrm{F}$ & 162.8 & 2.4 & 0.06 \\
\hline & $p$ & $<0.0001$ & ns & ns \\
\hline \multirow[t]{2}{*}{$\mathrm{C} / \mathrm{N}^{*}$} & $\mathrm{~F}$ & 22.03 & 0.98 & 0.29 \\
\hline & $p$ & $<0.0001$ & ns & ns \\
\hline
\end{tabular}

Significant effects are marked bold.

Log transformed; ns, non significant. 

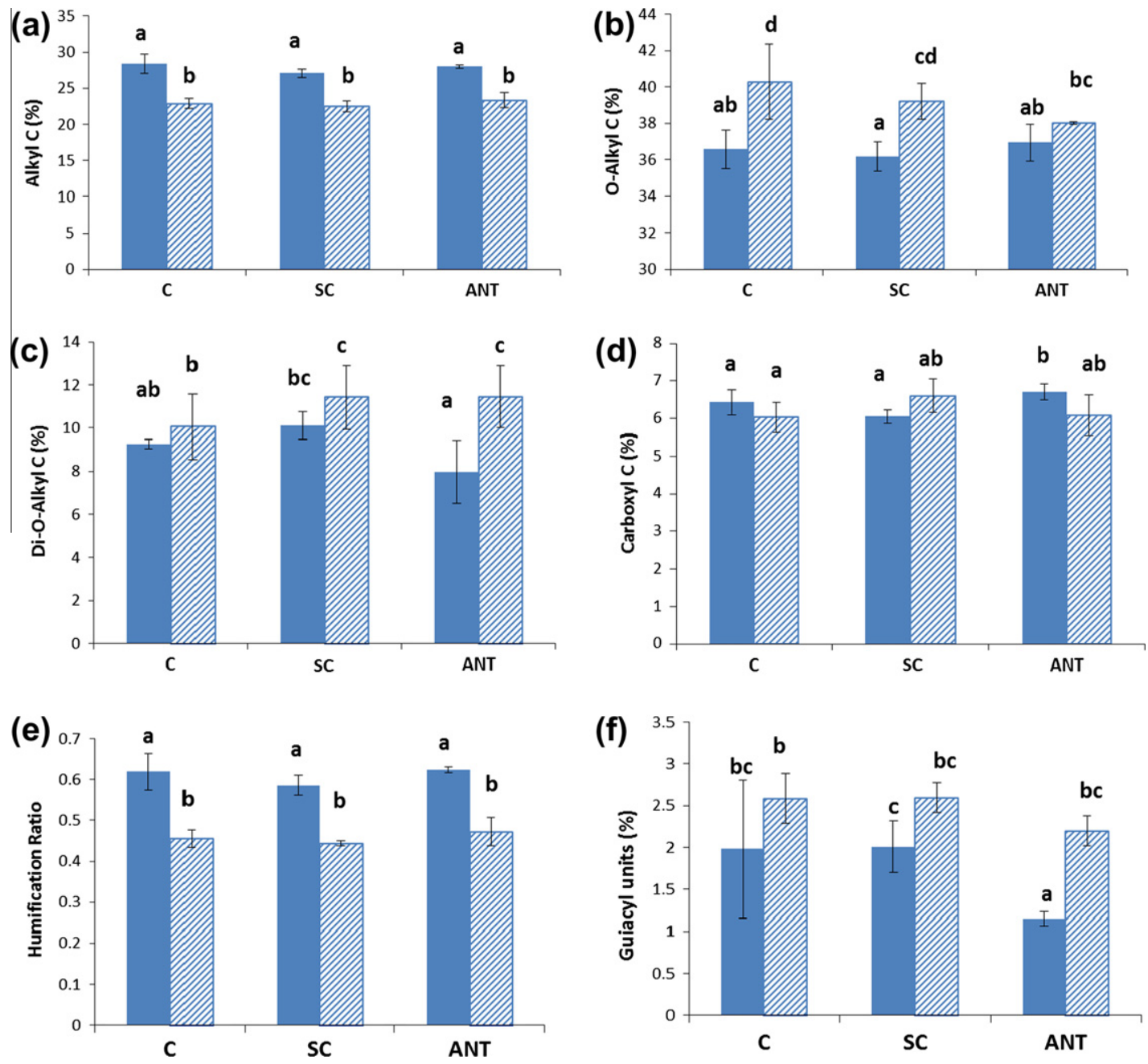

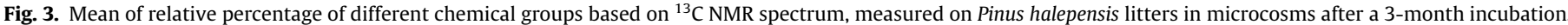

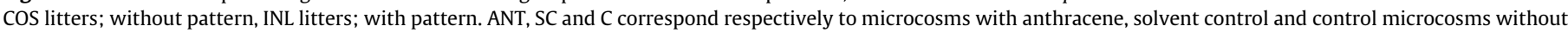

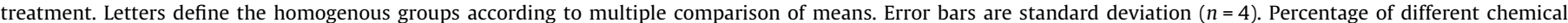

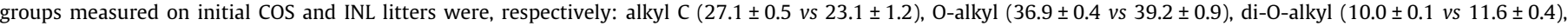
carboxyl $(5.8 \pm 0.4$ vs $6.1 \pm 0.1)$, humification ratio $(0.58 \pm 0.02$ vs $0.45 \pm 0.02)$ and guiacyl units $(2.6 \pm 0.5$ vs $2.7 \pm 0.3)$.

correlation to alkyl C. On the other hand, PC2 was mainly explained by a positive correlation with carboxyl and aromatic carbons.

\subsection{Correlation between chemical composition and enzyme activities}

Pearson's correlation between different chemical characteristics $\left({ }^{13} \mathrm{C}\right.$ NMR signals and $\left.\mathrm{C} / \mathrm{N}\right)$ and enzyme activities (laccase, cellulase, $\beta$-glucosidase and acid phosphatase) is shown in Table 3. Positive correlations were found between all the tested enzymes activities and alkyl $C$ and humification ratio; in particular, the correlation between laccases and alkyl $C$ was highly significant $(p<0.001)$. Except for $\beta$-glucosidase activity, we observed negative significant correlations between all the enzyme activities, and di-O-alkyl C, guaiacyl units, and $\mathrm{C} / \mathrm{N}$ ratio in microcosms. We obtained a significant positive correlation between cellulase activities and carboxyl $C$ and a significant negative correlation between phenolic $C$ and laccase activities $(p<0.05)$.

\section{Discussion}

Here, we tested whether the microbial communities of litter from the same plant species but from different sites (coastal versus inland areas), under favorable conditions (temperature and humidity) in laboratory, are affected in the same way by anthracene. Chemical characterization of both litters at t0 revealed that the INL litter is composed of more labile carbon than that of COS litter as shown in Fig. 4b. Moreover, microbial activities of litters from COS and INL were different before testing the effect of anthracene in microcosms. Both microbial and chemical differences were more intensified after incubation under laboratory conditions.

The decrease in $\mathrm{C} / \mathrm{N}$ ratio over incubation (via an increase in total $\mathrm{N}$ of all microcosms) confirms that our experimental conditions conducive to microbial growth in microcosms especially in COS and to a less extent in INL litters. However, the overall activity of microbial communities, here estimated by respiration, slows down in microcosms comparing to their natural level in the environment. As well, a dramatic reduction on microbial induced respiration is found in all microcosms, usually considered as an indicator of microbial biomass (Anderson and Domsch, 2010). This result showed that, laboratory incubation conditions had a drastic effect on the whole microbial activities and biomass production.

Enzyme activities in litter, produced by both fungal and bacterial communities, are commonly used as indicators of functional diversity of microbial communities (Wallenstein and Weintraub, 2008; Burke et al., 2011). Here we used specific enzyme detection and microbial respiration to assess the effect of our model PAH, 

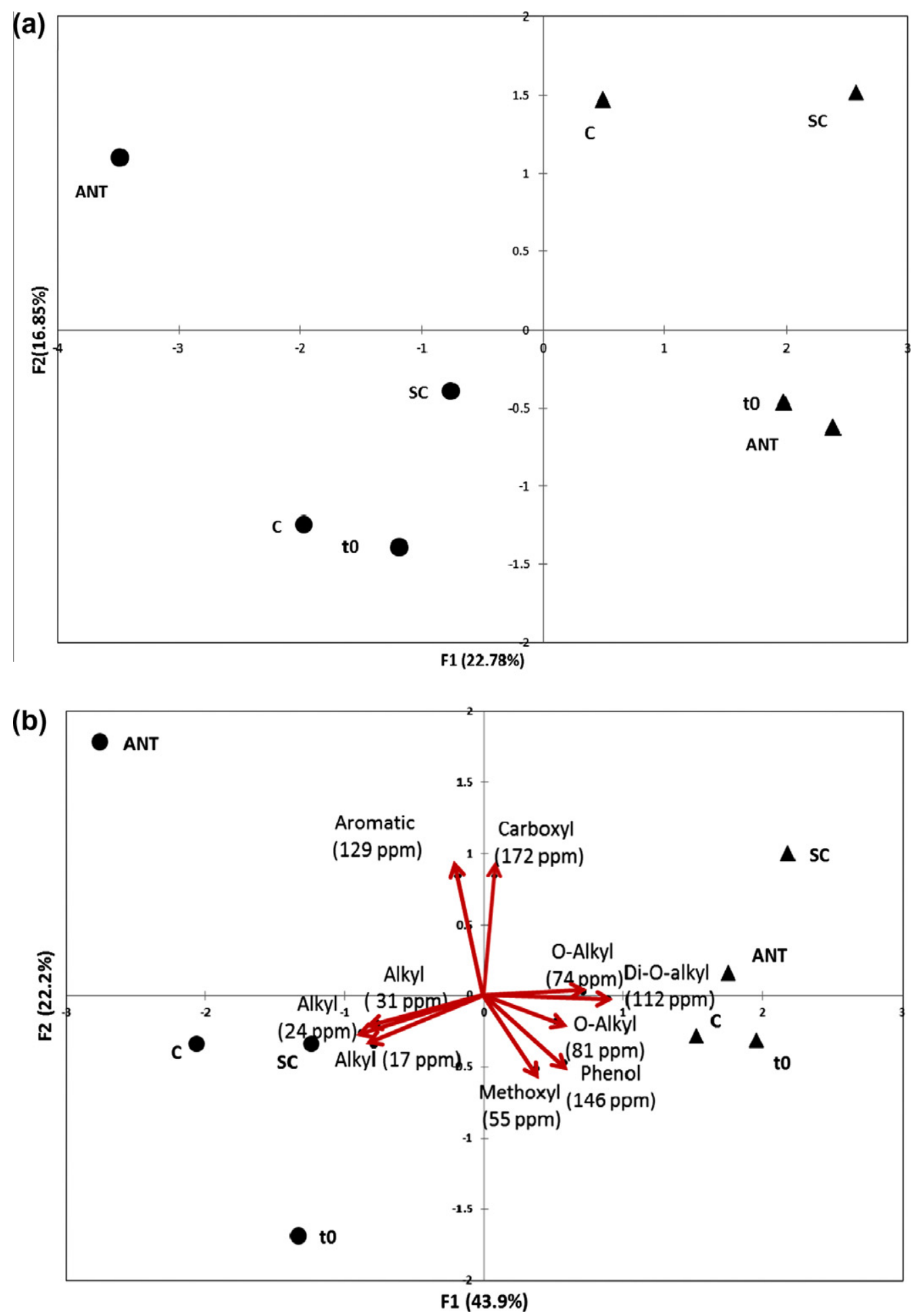

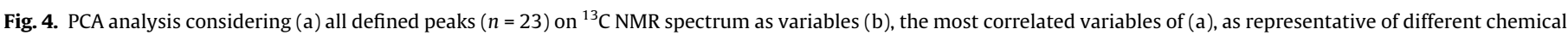
groups. COS and INL microcosms are presented as circles and triangles, respectively.

anthracene, on microbial functioning. Interestingly, we found that microbial communities from coastal litter are more active with respect to enzyme activities and respiration in transforming available substrates in the litter. Basal respiration was higher in COS litter after incubation, while, when glucose was added as a carbon source, the respiration level was nearly the same for both litters. This highlights that, after 3 month incubation, microbial communities in COS are more active than those in INL for the same biomass amount in both microcosms. This also suggests that the INL litter communities were carbon-limited compared to those in COS.

Moreover, regarding enzyme activities, we detected a concomitant increase in both laccase and cellulase activities in COS litter, whereas the same lignocellulolytic activities were detected in initial litters of both sites. These increases can be directly linked to 
Table 3

Pearson correlation between chemical groups defined from ${ }^{13} \mathrm{C}$ NMR spectra and enzyme activities measured on Pinus halepensis litters in micrcosms ( $n=24$ )

\begin{tabular}{|c|c|c|c|c|}
\hline Chemical characteristics & Laccase & Cellulase & $\beta$-Glucosidase & Acid phosphatase \\
\hline Alkyl C & $0.77^{* * *}$ & $0.49^{*}$ & $0.59^{* *}$ & $0.71^{* *}$ \\
\hline Methoxyl C & -0.32 & -0.37 & 0.12 & -0.34 \\
\hline O-Alkyl C & -0.42 & -0.15 & -0.45 & -0.41 \\
\hline di-O-Alkyl C & $-0.70^{* *}$ & $-0.67^{* *}$ & -0.31 & $-0.55^{*}$ \\
\hline Aromatic C & 0.06 & 0.32 & -0.28 & -0.03 \\
\hline Phenolic C & $-0.55^{*}$ & -0.46 & -0.40 & -0.47 \\
\hline Phenolic C (C3-C4 of Guiacyl units) & $-0.73^{* *}$ & $-0.72^{* *}$ & -0.04 & $-0.53^{*}$ \\
\hline Carboxyl C & 0.46 & $0.50^{*}$ & -0.03 & 0.43 \\
\hline Aromaticity ratio & -0.15 & 0.14 & -0.42 & -0.22 \\
\hline Humification ratio & $0.77^{* * * *}$ & $0.52^{*}$ & $\mathbf{0 . 5 9}{ }^{*}$ & $0.69^{* *}$ \\
\hline $\mathrm{C} / \mathrm{N}$ & $-0.53^{* *}$ & -0.35 & -0.25 & $-0.64^{* *}$ \\
\hline
\end{tabular}

Significant correlations are marked with bold.

$p<0.05$.

*** $p<0.01$.

${ }^{* *} p<0.001$.

more intense fungal development, which generally leads to greater quantities of extracellular enzymes (Sánchez, 2009; Burke et al., 2011). Thus, under our laboratory conditions, the development of certain microbial communities was favored depending on the origins of litters. Furthermore, the responses of the microbial communities in COS litters are strongly influenced by the presence of an aromatic pollutant. This suggests that the environmental conditions in coastal areas faster microbial communities with a special potential for recalcitrant compound decomposition. This result could have implications for detoxification processes especially in such environment that is known to be greatly impacted by anthropogenic pollution.

Natural recalcitrant molecules i.e. lignin, or anthropogenic compounds such as PAHs, can sometimes be used as carbon and/or energy sources for degrading microorganisms during detoxification (Andreoni and Gianfreda, 2007). However, recalcitrant compounds generally do not serve as growth substrates for a single microorganism, but rather are thought to be oxidized in several steps by consortia of microbes (Perry, 1979). Laccases, phenoloxidases generally produced by fungal communities, are one of the most important groups of enzymes degrading a wide variety of recalcitrant molecules, and as such are of great interest in bioremediation processes for contaminated sites (Baldrian, 2006; Haritash and Kaushik, 2009; Sinsabaugh, 2010). Our finding demonstrate that, under favorable conditions, high production of extracellular enzymes can be obtained concomitantly with fungal growth, showing that microbial communities from coastal ecosystems may be particularly adapted to transforming both natural and anthropogenic refractory molecules.

These results are corroborated by the chemical variations in the litter revealed by aromatic signals from NMR. The anthracene effect on chemical variations was especially correlated to the guaiacyl unit signal: after incubation in the presence of anthracene, this signal decreases in COS litter. High negative correlation between lignocellulolytic enzymes and guaiacyl units, which are known to be free phenolic units of lignin in pine litters, also corroborated this result (Lorenz et al., 2004). This finding shows that together with the origin of litter, anthracene is a factor influencing microbial activities.

On the basis of PCA of chemical composition of litters considered together with microbial activities, our results reveal that incubation slows down certain microbial activities in INL litter, while the same activities in COS litter seem to be intensified, especially in the presence of anthracene. Higher activities in COS litter may lead to high biomass production: the increase in alkyl $C$ intensity in COS litters may be linked to higher microbial development correlated with microbial-produced carbon due to lipids of membrane (Mathers et al., 2007). This confirms previous findings (Fahy et al.,
2005) showing that pollutants do not always affect microbial activities. Here we focused on the functioning of autochtonous microbial communities but further studies should investigate how PAH may influence the microbial community structure of litters from either coastal or inland areas.

\section{Conclusion}

In this study, anthracene did not show any toxic effects on microbial activities of either coastal or inland litters, indicating that the influence of a pollutant on microbial activities and organic matter mineralization in litters from these ecosystems is not as high as was initially hypothesized. This finding is of major importance regarding contamination with aromatic pollutants, since it indicates that autochthonous microbial communities from coastal litters appear to better transform organic matter, including recalcitrant compounds. Thus environmental constraints from coastal areas appear to structure microbial communities in a different way compared with those in inland areas. More investigations should be performed through in situ studies in Mediterranean coastal environments to understand how multi-contaminations may structure microbial communities and influence their functions.

\section{Acknowledgments}

This work is financially supported by a $\mathrm{PhD}$ grant from the French Environment and Energy Management Agency (ADEME) and the Provence Alpes Côte d'Azur Region (France) to L. QASEMIAN. We thank Mrs. Marjorie Sweetko for her assistance with English.

\section{References}

Anderson, T.H., Domsch, K.H., 2010. Soil microbial biomass: the eco-physiological approach. Soil Biol. Biochem. 42, 2039-2043.

Andreoni, V., Gianfreda, L., 2007. Bioremediation and monitoring of aromaticpolluted habitats. Appl. Microbiol. Biotechnol. 76, 287-308.

Asia, L., Mazouz, S., Guiliano, M., Doumenq, P., Mille, G., 2009. Occurrence and distribution of hydrocarbons in surface sediments from Marseille Bay (France). Mar. Pollut. Bull. 58, 443-451.

Ayres, E., Steltzer, H., Berg, H., Wallenstein, M.D., Simmons, B.L., Wall, D.H., 2009 Tree species traits influence soil physical, chemical, and biological properties in high elevation forests. PLoS ONE 4, e5964. http://dx.doi.org/10.1371/ journal.pone.0005964.

Baldock, J.A., Oades, J.M., Preston, C.M., Nelson, P.N., Skene, T.M., Golchin, A., Clark, P., 1997. Assessing the extent of decomposition of natural organic materials using solide state ${ }^{13} \mathrm{C}$ NMR spectroscopy. Aust. J. Soil Res. 35, 1061-1083.

Baldrian, P., 2006. Fungal laccases-occurence and properties. Fems Microbiol. Rev. 30, 215-242.

Berg, B., Laskowski, R., 2006. Litter decomposition: a guide to carbon and nutrient turnover. Adv. Ecol. Res. 38 
Berg, B., McClaugherty, C., 2008. Plant Litter: Decomposition, Humus Formation, Carbon Sequestration, second ed. Springer Verlag, Heidelberg, Berlin.

Burke, D.J., Weintraub, M.N., Hewins, C.R., Kalisz, S., 2011. Relationship between soil enzyme activities, nutrient cycling and soil fungal communities in a northern hardwood forest. Soil Biol. Biochem. 43, 795-803.

Costa, R., Götz, M., Mrotzek, N., Lottmann, J., Berg, G., Smalla, K., 2006. Effects of site and plant species on rhizosphere community structure as revealed by molecular analysis of microbial guilds. FEMS Microbiolo. Ecol. 56, 236-249.

Criquet, S., Tagger, S., Vogt, G., Lacasio, G., Le petit, J., 1999. Laccase activity of forest litter. Soil Biol. Biochem. 31, 1239-1244.

D’Annibale, A., Rosetto, F., Leonardi, V., Federici, F., Petruccioli, M., 2006. Role of autochthonous filamentous fungi in bioremediation of a soil historically contaminated with aromatic hydrocarbons. Appl. Environ. Microbiol. 72, 28-36.

Fahy, A., Lethbridge, G., Earle, R., Ball, A.S., Timmis, K.N., McGenity, T.J., 2005. Effects of long-term benzene pollution on bacterial diversity and community structure in groundwater. Environ. Microbiol. 7, 1192-1199.

Farnet, A.M., Qasemian, L., Guiral, D., Ferré, E., 2010. A modified method based on arsenomolybdate complex to quantify cellulase activities: application to litters Pedobiologia 53, 159-160.

Fernández-Luqueño, F., Valenzuela-Encinas, C., Marsch, R., Martínez-Suárez, C. Vázquez-Núñez, E., Dendooven, L., 2011. Microbial communities to mitigate contamination of PAHs in soil-possibilities and challenges: a review. Environ. Sci. Pollut. Res. 18, 12-30.

Gianfreda, L., Rao, M.A., 2004. Potential of extra cellular enzymes in remediation of polluted soils: a review. Enzyme Microb. Technol. 35, 339-354.

Haritash, A.K., Kaushik, C.P., 2009. Biodegradation aspects of Polycyclic Aromatic Hydrocarbons (PAHs): a review. J. Hazard. Mater. 169, 1-15.

Holoubek, I., Ansorgova, A., Korinek, P., Kohoutek, J., Staffova, K., Paschova, Z. Holoubkova, I., Mitera, J., 2000. The spatial and temporal variations of polycyclic aromatic hydrocarbons (PAHs) in environmental matrices in the Czech Republic. Polycycl. Aromat. Compd. 20, 67-77.

Howsam, M., Jones, K.C., Ineson, P., 2001. Dynamic of PAH deposition, cycling and storage in a mixed-deciduous (Quercus fraxinous) woodland ecosystem. Environ. Pollut. 113, 163-176.

Johnsen, A.R., Wick, L.Y., Harms, H., 2005. Principles of microbial PAH-degradation in soil. Environ. Pollut. 133, 71-84.

Johnsen, A.R., Karlson, U., 2007. Diffuse PAH contamination of surface soils: environmental occurrence, bioavailability, and microbial degradation. Appl. Microbiol. Biotechnol. 76, 533-543.

Lorenz, K., Preston, C.M., Krumrei, S., Feger, K.H., 2004. Decomposition of needle/lea litter from Scots pine, black cherry, common oak and European beech at a conurbation forest site. Eur. J. For. Res. 123, 177-188.

Marusenko, Y., Herckes, P., Hall, S.J., 2011. Distribution of polycyclic aromatic hydrocarbons in soils of an arid urban ecosystem. Water Air Soil Pollut. 219, 473-487.

Massiot, D., Fayon, F., Capron, M., King, I., Le Calve, S., Alonso, B., Durand, J.O., Bujoli, B., Gan, Z.H., Hoatson, G., 2002. Modelling one- and two-dimensional solid-state NMR spectra. Magn. Reson. Chem. 40, 70-76.
Mathers, N.J., Mendham, D.S., O'Connell, A.M., Grove, T.S., Xu, Z., Saffign, P.G., 2003. How does residue management impact soil organic matter composition and quality under Eucalyptus globulus plantations in southwestern Australia? For. Ecol. Manage. 179, 253-267.

Mathers, N.J., Jalota, R.K., Dalal, R.C., Boyd, S.E., 2007. ${ }^{13}$ C-NMR analysis of decomposing litter and fine roots in the semi-arid Mulga Lands of southern Queensland. Soil Biol. Biochem. 39, 993-1006.

Mille, G., Asia, L., Guiliano, M., Malleret, L., Doumenq, P., 2007. Hydrocarbons in coastal sediments from the Mediterranean sea (Gulf of Fos area, France). Mar. Pollut. Bull. 54, 566-575.

Nazareno Saparrata, M.C., Roccad, M., Aulicino, M., Arambarri, A.M., Balatti, P.A., 2008. Celtis tala and Scutia buxifolia leaf litter decomposition by selected fungi in relation to their physical and chemical properties and lignocellulolytic enzyme activity. Eur. J. Soil Biol. 47, 400-407.

Novotný, Č., Svobodová, K., Erbanová, P., Cajthaml, T., Kasinatha, A., Lang, E., Šašek, V., 2004. Ligninolytic fungi in bioremediation: extracellular enzyme production and degradation rate. Soil Biol. Biochem. 36, 1545-1551.

Perry, J.J., 1979. Microbial cooxidations involving hydrocarbons. Microbiol. Rev. 43, 59-72.

Qasemian, L., Guiral, D., Belgazi, M., Gros, R., Ferré, E., Farnet, A.M., 2011. Identification of various laccases induced by anthracene and contribution to its degradation in a Mediterranean coastal pine litter. Chemosphere 84, 13211328.

Qasemian, L., Guiral, D., Ziarelli, F., Dang, T.K.V., Farnet, A.M., 2012. Effects of anthracene on microbial activities and organic matter decomposition in a Pinus halepensis litter from a Mediterranean coastal area. Soil Biol. Biochem. 46, 148154.

Sánchez, C., 2009. Lignocellulosic residues: biodegradation and bioconversion by fungi. Biotechnol. Adv. 27, 185-194.

Sariyildiz, T., Anderson, J.M., Kucuk, M., 2005. Effects of tree species and topography on soil chemistry, litter quality, and decomposition in Northeast Turkey. Soil Biol. Biochem. 37, 1695-1706.

Sinsabaugh, R.L., 2010. Phenol oxidase, peroxidase and organic matter dynamics of soil. Soil Biol. Biochem. 42, 391-404.

Sorgi, K., 2007. Monitoring of environmental exposure to polycyclic aromatic hydrocarbons: a review. Environ. Chem. Lett. 5, 169-195.

Strickland, M.S., Osburn, E., Lauber, C., Fierer, N., Bradford, M.A., 2009. Litter quality is in the eye of the beholder: initial decomposition rates as a function of inoculum characteristics. Funct. Ecol. 23, 627-636.

Wallenstein, M.D., Weintraub, M.N., 2008. Emerging tools for measuring and modeling the in situ activity of soil extracellular enzymes. Soil Biol. Biochem. 40, 2098-2106.

Wu, Y., Teng, Y., Li, Z., Liao, X., Luo, Y., 2008. Potential role of polycyclic aromatic hydrocarbons (PAHs) oxidation by fungal laccase in the remediation of an aged contaminated soil. Soil Biol. Biochem. 40, 789-796.

Yutthammo, C., Thongthammachat, N., Pinphanichakarn, P., Luepromchai, E., 2010. Diversity and activity of PAH-degrading bacteria in the phyllosphere of ornamental plants. Microb. Ecol. 59, 357-368. 